\title{
ON POSSIBILITIES AND METHODS OF ANALYSIS OF THEMATIC EXPRESSIONS IN SPOKEN TEXTS
}

\author{
PETR POŘÍZKA \\ Faculty of Arts, Palacký University, Olomouc, Czech Republic
}

POŘÍZKA, Petr: On possibilities and methods of analysis of thematic expressions in spoken texts. Journal of Linguistics, 2019, Vol. 70, No 2, pp. $469-480$.

\begin{abstract}
The treatise focuses on mutual comparison of three methods of detection of prominent text units (prominent in relation to the contents of the text). The methods are: 1) analysis of key words based on comparison of source and referential corpora, 2 ) thematic concentration and h-point, and 3 ) the TF*IDF method. We try to thematize their pros and cons and, using the results of the carried out analyses, propose the optimal method for the extraction of thematic words from the spoken texts the frequency structure of which differs distinctly from the frequency structure of written texts.
\end{abstract}

Keywords: corpus linguistics, corpus lexicography, dialect corpora

\section{INTRODUCTION}

Quantitative linguistics disposes of methods that are used to recognize main topic(s) of texts or keywords in the texts. Methods of extraction of these so-called prominent units are tested on texts of different genres and they are predominantly used to analyze written texts. This study intends to find out to what extent the selected methods of analysis can be used to extract prominent units in spoken texts. It is well known that in its form spoken language often differs distinctly from written language. From the quantitative viewpoint, the difference is evident even if we compare frequency vocabulary of spoken and written texts. Spoken dialogues have a specific frequency structure and a clearly distinct frequency distribution of individual parts of speech (henceforth POS). This fact can have relevant consequences since these methods of analyzing prominent units are based on word lists (or on the comparison of those lists) and on frequency structure of texts. Let us now see frequency structure of POS in large corpora of written Czech included in the Czech National Corpus (CNC; the column $C N C$-written represents the average values of POS of the SYN line of corpora) and in representative spoken corpora of $\mathrm{CNC}$ (the column CNC-spoken represents the average values of POS of ORALv1 and ORTOFONv1 corpora). In the table, relative frequency in per cent is stated. ${ }^{1}$

${ }^{1}$ Partial corpora of the SYN line contain approximately 100 million words, ORALv1 includes about 5.5 mil. words and ORTOFONv1 about 1 mil. words. 


\begin{tabular}{|l|r|r|}
\hline POS & CNC-written & CNC-spoken \\
\hline Noun & 30.53 & 11.41 \\
\hline Adj & 11.48 & 3.50 \\
\hline Pron & 10.48 & 20.27 \\
\hline Num & 3.17 & 2.04 \\
\hline Verb & 16.86 & 20.15 \\
\hline Adv & 7.10 & 12.84 \\
\hline Prep & 10.55 & 5.67 \\
\hline Conj & 7.56 & 11.48 \\
\hline Part & 0.99 & 8.38 \\
\hline Interj & 0.05 & 0.42 \\
\hline resp+hes & ---- & 2.15 \\
\hline uncomp & --- & 1.04 \\
\hline unknown & 1.26 & 0.65 \\
\hline
\end{tabular}

Tab. 1. Frequency distribution of parts of speech in written and spoken corpora of CNC. Number represent relative frequency in per cent. Legend: resp+hes = response and hesitation; uncompl = uncompleted words; unknown = expressions not recognized by a tagger

As we can see, the differences are manifested most significantly in the distribution of nouns: the frequency of their appearance in spoken texts is distinctly lower than in written texts (approx. 30\% written vs. 11\% spoken); a similarly distinct decrease is documented in the distribution of adjectives (approx. 11.5\% vs. 3.5\%) and prepositions (approx. 10.5\% vs. 5.5\%). On the other hand, the frequency of adverbs (7\% vs. $13 \%$ ) and particles (1\% vs. $8 \%$ ) rises. $^{2}$ As we will demonstrate, thematic expressions are extracted from nouns, adjectives and verbs. And nouns, as expressions signifying substances, are undoubtedly significant for any method the aim of which is to detect prominent text units. On the basis of these differences we intend to find out to what extent the perceptibly lower frequency distribution of nouns (and possibly even other differences) will be manifested in our analyses carried out with the use of selected methods.

\section{DATA, METHODS, TOOLS}

For our probe we chose two of currently often used methods of extraction of prominent units: 1) analysis of keywords and 2) the method of measuring thematic text concentration, namely the part of the method in which thematic words are detected. The third method is 3) TF*IDF method (Term Frequency vs. Inverse Document Frequency), used in semantic analysis of texts. In the text analyses, following freely available software tools were applied: (ad 1) KWords [1], (ad 2) QUITA [2], and (ad 3) KER - Keyword Extractor [3].

${ }^{2}$ Among particles even hesitation and response sounds might be included (the category of resp + hes in Table 1); thus their proportional representation would rise by $2 \%$ to the final proportion of $10 \%$. 
The analyzed data were formed by 20 spoken texts randomly selected from the socalled Olomouc spoken corpus (henceforth OSC) [4]. We used orthographically normalized/standardized versions of transcripts that were further purified in order to suit our intentions. We removed all their parts that could affect textual analysis: particularly marks of individual speakers (before all lines) and all meta-textual marks and commentaries. Individual transcripts contained between 2,300 and 4,500 words (the average of 3,135 words in a transcript); the overall size of the dataset was 62,694 words.

The transcripts were subsequently lemmatized for KWords and KER with the use of MorphoDiTa, a morphological analyzer and tagger [5]. While working with QUITA we used a morphological analyzer Majka [6].

Quantitative analysis of so-called keywords (further on also KWs) ([7], [8]), based on the comparison of the source text (SourceC) with so-called referential corpus (RefC) is certainly one of the most commonly used methods of content analysis of texts. For keywords we take the words the frequency of which is remarkably higher in the SourceC than in the RefC. Nevertheless, the choice of the RefC influences even the overall result of the analysis and it is therefore recommended to choose textually neutral databases that reflect common language usage. For the detection of statistic relevance of differences two statistical tests are used: log-likelihood and chi-squared test. Even this exact method has its difficulties that have to be faced, namely with respect to appropriate combination of computing parameters. It is primarily necessary to set the level of statistic significance of the test (most frequently to $0.05,0.01,0.001$, or even more) and sometimes other parameters (see below Sec. 3.2). It is also possible to apply so-called stop-lists on the text; by stop-lists we mean the lists of words or word groups that are a priori excluded from the analysis of KWs. Among problematic aspects of this kind of analysis belongs the fact that the analysis produces quite large lists of detected KWs (sometimes containing hundreds or even more words) that have to be in some way reduced in order to be used in subsequent analysis and interpretation of the text. Such reductions are often arbitrary, based on some ad hoc criteria: most frequently only the group of the initial 20,50 or 100 words is taken from the list of all detected KWs and applied in the interpretation. That is why even the position of a certain keyword in the final list is important, the position reflecting a simple principle: the higher in the list the KW appears, the more relevant it is for the contents and topic(s) of the text. In this way KWs are hierarchized; KWs can certainly be sorted out according to the coefficient of the main statistical test. We can also use any index reflecting the relevance of different distribution of the word in the SourceC and in the RefC, or the index applied in order to neutralize the different sizes of source and referential corpora. For example, in the latest version (3.5.8) of a concordance tool AntConc [9] 10 indexes of this kind are implemented. ${ }^{3}$

\footnotetext{
${ }^{3}$ Compare individual indexes in the menu of Keyword Effect Size Measure.
} 
The above stated characteristics of keyword analysis show that this is a relatively demanding procedure during which one must set many parameters that affect the process and the resulting list of KWs. Researchers therefore look for other ways and methods leading to the revelation of main topics of texts. Recently, namely the analysis of thematic words has been tested and developed that utilizes measuring of thematic text concentration (further on also TC) [10]. The method is based on simple extraction of thematic words (TW) from a word list; to detect thematic words one needs no external database nor further mathematical modeling of the text that would prefer certain words to others and modify their position in the word list. The method considers as thematic the words that occupy the positions above so-called $h$-point in the word list, while the $h$-point is defined as a position in which the rank of the word equals the frequency of the word. ${ }^{4}$ The $h$-point concurrently represents an indistinct borderline between autosemantic and synsemantic POS: all autosemantic expressions, with the exception of adverbs and certain verbs (see below) that appear above the $h$-point are subsequently considered as main topics of the text.

Nevertheless, in practice the use of the method often results in empty TW sets. The texts with an empty set of thematic words are subsequently considered as thematically neutral while the texts in which one detects TWs are thematically determined. In order to eliminate the cases of empty TW sets, the so-called STC (secondary thematic concentration) was implemented in the method which means that the TC value is multiplied by 2 in order to shift the $h$-point lower in the word list and to increase the chance of finding some prominent units. We consider this solution as rather problematic since it is quite arbitrary and it leaves without explanation why TC values are multiplied by 2 and not by other numbers. But there is also a question: Isn't the choice of $h$-point arbitrary in itself?

The choice of an elementary text unit is methodologically relevant as well. Shall it be the word form, a lemma, or even other unit? It is common to take a text form as the elementary unit of the analysis but it is evident (from previous analyses) that in case of a strongly inflective Czech lemma is definitely a more appropriate choice since it represents all text forms of a lexeme.

\section{ANALYSIS AND INTERPRETATION OF ITS RESULTS 5}

\subsection{TC and thematic expressions}

Lemma is the elementary unit of our analyses. Besides their lemmatization we annotated the texts even morphologically - we assigned the mark of its affiliation with a particular part of speech to each text unit. In Table 2 below we indicate frequency distribution of individual POS in our specimen of data in comparison with

\footnotetext{
${ }^{4}$ For comments to the formula and to the calculation of the $h$-point see [10] (pp. $11 \mathrm{nn}$ ).

${ }^{5}$ Here we will restrict ourselves to interpretational remarks. Complete resulting lists of KWs are available and can be freely downloaded at: http: / / corpus. upol.cz/system/files/KWs-lists.zip.
} 
morphologically annotated spoken CNC corpora. Since we applied two different taggers (see Sec. 2) both variants of annotation are presented in the table:

\begin{tabular}{|l|r|r|r|r|}
\hline POS & $\begin{array}{c}\text { OSCsample20 } \\
\text { MorphoDiTa }\end{array}$ & $\begin{array}{c}\text { OSCsample20 } \\
\text { Majka }\end{array}$ & ORAL v1 & ORTOFON v1 \\
\hline Noun & 13.59 & 12.19 & 11.63 & 11.18 \\
\hline Adj & 4.03 & 4.02 & 3.63 & 3.38 \\
\hline Pron & 20.37 & 20.33 & 20.86 & 19.67 \\
\hline Num & 1.89 & 1.81 & 1.77 & 2.31 \\
\hline Verb & 21.8 & 21.67 & 20.46 & 19.84 \\
\hline Adv & 14.37 & 15.5 & 12.93 & 12.74 \\
\hline Prep & 5.92 & 5.96 & 5.66 & 5.69 \\
\hline Conj & 11.84 & 11.67 & 11.51 & 11.46 \\
\hline Part & 5.3 & 4.51 & 8.13 & 8.63 \\
\hline Interj & 0.91 & 0.77 & 0.43 & 0.4 \\
\hline resp+hes & --- & --- & 1.64 & 2.67 \\
\hline uncomp & --- & --- & 0.75 & 1.33 \\
\hline unknown & 0 & 1.62 & 0.6 & 0.7 \\
\hline
\end{tabular}

Tab. 2. Comparison of frequency distribution of POS in the analyzed specimen of spoken data (OSCsample20) and in the spoken CNC corpora. The numeric values signify relative frequency in per cent.

he comparison enables us to suppose that the selected specimen of spoken data can be considered as representative since the frequency distributions of POS correspond with those in much larger databases (OSCsample20: $\doteq 63$ thousand; ORTOFON: $\mathrm{N} 1.03 \doteq$ million; ORAL: $\mathrm{N} \doteq 5.5$ million words). It is significant, namely with respect to the TC method and its POS limitation of thematic words. We notice certain deviations (for example in the frequency distributions of particles, adverbs or nouns) but they are only minute (avg. $1.5 \%$ in case of nouns, $2.1 \%$ in case of adverbs, and $3.5 \%$ in case of particles) and therefore they cannot affect the analysis of thematic words. The proportional representation of nouns in OSCsample 20 is even slightly higher than in the $\mathrm{CNC}$ corpora.

The results of the analysis of thematic words carried out with the use of QUITA tool are presented in Table 3:

\begin{tabular}{|c|l|}
\hline DOC & TWs according to TC \\
\hline 1 & vědět 'to know', jít 'to go' \\
\hline 2 & $\mathbf{0}$ \\
\hline 3 & vědět 'to know', ř́kat 'to say' \\
\hline 4 & $\mathbf{0}$ \\
\hline 5 & vědět 'to know' \\
\hline
\end{tabular}




\begin{tabular}{|l|l|}
\hline 6 & vědět 'to know' \\
\hline 7 & vědět 'to know', hrát 'to play', dělat 'to do' \\
\hline 8 & $\mathbf{0}$ \\
\hline 9 & řikat 'to say', vědět 'to know' \\
\hline 10 & rok 'year', fotbal 'soccer' \\
\hline 11 & vědět 'to know', koupit 'to buy' \\
\hline 12 & vědět 'to know' \\
\hline 13 & jít 'to go' \\
\hline 14 & vědět 'to know', jet 'to go', jezdit 'to go' \\
\hline 15 & $\mathbf{0}$ \\
\hline 16 & vědět 'to know' \\
\hline 17 & $\mathbf{0}$ \\
\hline 18 & jet 'to go', vědět 'to know' \\
\hline 19 & vědět 'to know' \\
\hline 20 & dobrý 'good', vědět 'to know' \\
\hline
\end{tabular}

Tab. 3. Results of the analysis of thematic words in spoken texts (OSCsample20).

TWs are arranged according to their ranking.

In 5 out of 20 texts, i.e. in $25 \%$ of cases, no thematic words were found - they are texts Nos 2, 4, 8, 15 and 17 (mind their absence in Table 3). In all remaining documents only 11 different prominent units were found. We suppose that only some of them can be considered as real thematic words. Particularly they are these: hrát 'to play', koupit 'to buy', rok 'year', fotbal 'soccer'. They are marked by bold print in Table 3 and they were found only in 3 out of 20 texts. Other lexemes rather indicate deviation from semantic (thematic) to pragmatic use (we verified the character of their behavior with the use of concordances in our corpus). It is true namely in case of the verb vědět ('to know', a verb of mental action, communication) that appeared in 13 out of 15 texts or in the cases of ríkat ('to say', v. dicendi, communication) and dobrý ('good', an evaluative adjective). As prominent units only two other verbs were detected: dělat ('to do', v. faciendi), and jit/jet/jezdit ('to go', v. movendi).

A question arises whether it is possible to take the lexeme with noticeably pragmatic use for thematic expression. In spoken texts such lexemes often function as phatic, conative or emotional/expressive words while real thematic words should function as referential units (that signalize the relation to the topic).

The situation slightly improves in case of the STC index (Table 4). Nevertheless, we consider (as we stated above) STC as methodologically problematic. Besides, the authors of TC consider the texts without TWs as thematically neutral and the texts 
with TWs as thematically determined. A paradoxical situation thus arises in which the same texts with originally empty TW sets suddenly, thanks to STC, become thematically determined.

\begin{tabular}{|c|c|}
\hline DOC & TWs according to STC \\
\hline 1 & (vědět 'to know'), jít 'to go', dělat 'to do', (říci 'to say'), (říkat 'to say') \\
\hline 2 & $\begin{array}{l}\text { baterka 'flashlight', dát 'to give', (vědět 'to know'), udělat 'to do', (ř́kat 'to } \\
\text { say'), třešeň 'cherry' }\end{array}$ \\
\hline 3 & (vědět ‘to know'), (ř́kat ‘to say’), (ř́íci ‘to say’) \\
\hline 4 & $\begin{array}{l}\text { (vědět 'to know'), potřebovat 'to need', lednička 'fridge', dát 'to give', udělat } \\
\text { 'to do', koupit 'to buy', jet 'to go' }\end{array}$ \\
\hline 5 & (vědět 'to know'), (ř́kat 'to say'), (myslit 'to think'), jet 'to go', dělat 'to do' \\
\hline 6 & $\begin{array}{l}\text { (vědět 'to know'), (hezký 'pretty'), (myslit 'to think'), (krásný 'beautiful'), } \\
\text { Krkonoše }\end{array}$ \\
\hline 7 & $\begin{array}{l}\text { (vědět 'to know'), hrát 'to play', dělat 'to do', dát 'to give', statistika } \\
\text { 'statistics', (říci 'to say'), kluk 'boy', zápas 'match', jít ‘to go', (mhm), } \\
\text { (myslit 'to think') }\end{array}$ \\
\hline 8 & $\begin{array}{l}\text { (vědět 'to know'), sval 'muscle', jet ‘to go', mozek 'brain', (ríkat 'to say'), } \\
\text { dělat 'to do' }\end{array}$ \\
\hline 9 & $\begin{array}{l}\text { (říkat 'to say'), (vědět 'to know'), jít 'to go', (dobrý 'good'), dívat 'watch', } \\
\text { napsat 'to write', psát 'to write' }\end{array}$ \\
\hline 10 & $\begin{array}{l}\text { rok 'year', fotbal 'soccer', hrát 'to play', (myslit 'to think'), jít 'to go', řada } \\
\text { 'row', celý 'all', hráč 'player', (ř́íci 'to say') }\end{array}$ \\
\hline 11 & $\begin{array}{l}\text { (vědět 'to know'), koupit 'to buy', libra 'pound', jit 'to go', dát 'to give', } \\
\text { (myslit 'to think') }\end{array}$ \\
\hline 12 & (vědět 'to know'), vidět 'to see', (myslit ‘to think'), (ř́kat 'to say’) \\
\hline 13 & $\begin{array}{l}\text { jít 'to go', (říkat 'to say'), (vědět 'to know'), pamatovat 'to remember', dítě } \\
\text { 'child', chodit 'to go' }\end{array}$ \\
\hline 14 & $\begin{array}{l}\text { (vědět 'to know'), jet 'to go', jezdit 'to go', (říkat 'to say'), jít 'to go', psát ‘to } \\
\text { write', týden 'week', škola 'school', Honza 'Johnny', přijet ‘to come', spát } \\
\text { 'to sleep' }\end{array}$ \\
\hline 15 & $\begin{array}{l}\text { (vědět 'to know'), jít 'to go', dělat 'to do', jet 'to go', člověk 'man', (dobrý } \\
\text { 'good') }\end{array}$ \\
\hline 16 & (vědět ‘to know'), jít ‘to go', (říkat ‘to say’), (dobrý 'good'), (říci ‘to say') \\
\hline 17 & Martin, (dobrý 'good'), (vědět 'to know') \\
\hline 18 & jet 'to go', (vědět 'to know'), jít 'to go', (dobrý 'good'), Skotsko 'Scotland' \\
\hline 19 & (vědět 'to know'), jít 'to go', přijít 'to come' \\
\hline 20 & $\begin{array}{l}\text { (dobrý 'good'), (vědět 'know'), fotka 'photo', jméno 'to go'name, vidět 'to } \\
\text { see', dívat 'to watch' }\end{array}$ \\
\hline
\end{tabular}

Tab. 4. Thematic words according to STC (OSCsample20).

TWs are arranged according to their ranking. 
This time thematic words were detected in all partial documents of the dataset. Even if the STC caused the growth of detected lexemes they are actually verbs (or adjectives) again, functioning as pragmatic (phatic) words. The words can further be gathered in groups that share the same word-formation base or form pairs in which one verb is imperfective and the other one perfective: řici-ríkat 'to say', délatudělat 'to do', psát-napsat 'to write', jit-prijít-chodit 'to go on foot', jet-jezdit 'to go'. Among adjectives we can find increments with the same meaning and function and belonging to the same category (evaluative words): dobry' 'good', hezky' 'pretty', krásný 'beautiful'.

On the basis of the behaviour of all prominent units in the spoken texts verified with the use of corpus concordances the prominent TC/STC words can be divided in three zones/categories:

1) non-thematic expressions with pragmatic function (such as dobry' 'good', hezký 'pretty', myslet 'to think', védět 'to know', ríkat 'to say') - in Table 4 they are stated in parentheses;

2) a broad transitional zone of borderline expressions: namely verbs and adjectives that can be recognized as both thematic and pragmatic (for example vidèt 'to see', divat se 'to watch', potřebovat 'to need'); these expressions appear repeatedly in most analysed texts;

3) truly thematic expressions (for example baterka 'torch', lednička 'fridge', zápas 'match', fotbal 'soccer', škola 'school' etc.) - they are almost solely nouns - in Table 4 they are stated in bold print.

If we sum the results of our analyses up they seem to suggest that, in case of spoken texts, the TC/STC method fails. It may be caused by the fact that spoken texts differ from the written texts significantly: they have a specific frequency structure of the text/vocabulary, they contain many pragmatically used expressions, functioning as phatic, conative or emotive words.

\subsection{KWords and key-lemmas}

We used the KWords tool and carried out the analysis with following settings:

- $\quad$ stop-list: pronouns, prepositions, conjunctions, numbers

- methods: log-likelihood

- $\quad$ significance level $(\alpha): 0.0001$

- minimal frequency: 3

- percentage of registered keywords: all significant types

- referential corpus: SYN2015

The list of keywords can be arranged according to DIN that signalizes the relevance of differences in KWs in the SourceC and RefC. We limit the list of lemmas to the units of high and highest prominence (DIN $>95) .{ }^{6}$

\footnotetext{
${ }^{6}$ For the calculation formula and more detailed description of DIN values see [1].
} 
We analysed 5 documents of the OSCsample 20 set; three of them (Nos 2, 4, and 8) had an empty TC set while in case of the remaining documents (Nos 7 and 11) the set was not empty. Given the extent of the study and the fact that the resulting list of keywords are rather large, we will limit ourselves merely to brief remarks and possible conclusions that follow from our analyses:

- The DIN index functionally and effectively reduces the number of keywords and it also hierarchizes KWs.

- If we limit the list of lemmas to the units of high (DIN: 95-97) and highest (DIN 98-100) prominence, the resulting lists will contain approx. 40 up to 60 words in the texts (cf. Below):

\begin{tabular}{|c|c|c|c|}
\hline DOC & DIN 95-97 & DIN 98-100 & DIN 95-100 \\
\hline 2 & 20 & 36 & 56 \\
\hline 4 & 16 & 38 & 54 \\
\hline 7 & 30 & 37 & 67 \\
\hline 8 & 13 & 43 & 56 \\
\hline 11 & 29 & 35 & 64 \\
\hline MEAN & $\mathbf{2 1 . 6}$ & $\mathbf{3 7 . 8}$ & $\mathbf{5 9 . 4}$ \\
\hline
\end{tabular}

Tab. 5. The number of keywords in KWords tool

- Only very few pragmatically used words appear in the lists: they are following particles (ano, jo, hm, no, tož) or interjections ( $a h a$, hele, jé) and should here be regarded not as prominent units but rather as pragmatically applied words.

- Frequency POS distribution of resulting keywords suggests that the highest positions in the list are actually occupied by thematically significant expressions:

\begin{tabular}{|l|r|r|}
\hline POS & FREQ & FREQ \% \\
\hline Noun & $\mathbf{1 3 4}$ & $\mathbf{4 4 . 9 7}$ \\
\hline Verb & $\mathbf{1 1 0}$ & $\mathbf{3 6 . 9 1}$ \\
\hline Adj & 22 & 7.38 \\
\hline Part & 18 & 6.04 \\
\hline Adv & 6 & 2.01 \\
\hline Interj & 6 & 2.01 \\
\hline Num & 2 & 0.67 \\
\hline Total & $\mathbf{2 9 8}$ & $\mathbf{1 0 0 . 0 0}$ \\
\hline
\end{tabular}

Tab. 6. Frequency distribution of POS in KWords tool

- Unlike in TC, certain adjectives (such as dětský 'childish', infekční 'infectious', levoruky' 'left-handed', etc.) and verbs (such as lyžovat 'to ski', pršet 'to rain', vylécit 'to rain', etc.), i.e. the words that can truly be regarded as thematically prominent. 
It seems that the analysis of keywords is more suitable for the detection of prominent units in spoken texts than the method based on thematic concentration of texts. $^{7}$

\subsection{KER and TF*IDF method}

TF*IDF method [11] compares the frequency of the word in the analysed text with the "reversed" frequency of the word in all documents. IDF expresses the "relevance" of the word: the more frequently a particular word appears in the documents the less relevant it is for the analysed text. From mathematical viewpoint the method is relatively simple:

$$
\begin{aligned}
\mathrm{TF}(\mathrm{t})= & (\text { Number of times term } \mathrm{t} \text { appears in a document }) / \\
& /(\text { Total number of terms in the document })
\end{aligned}
$$

$\operatorname{IDF}(\mathrm{t})=\log \mathrm{e}($ Total number of documents / Number of documents with term $t$ in it).

The demo version of KER - Keyword Extractor has certain limitations. We therefore carried out analyses with following settings: ${ }^{8}$

- TF*IDF threshold level: 0.05

- maximum number of keywords: 25

This setting has turned out as optimal in majority of the analysed texts: the resulting number of KWs is lower than the pre-set maximum limit (5 out of 20 texts reached the maximum limit). Moreover, it turned out that the detected number of KWs does not depend directly on the length of the text. Texts Nos 1, 4, and 14 that reached the maximum limit of $25 \mathrm{KWs}$ do not even contain the average number of words. By the way of contrast, texts Nos 4 and 10 (approx. 2,300 words) and texts Nos 13 and 17 (approx. 3,000 words) are almost equally long. Nevertheless, the numbers of KWs that were found in texts of the same length differ diametrically: doc4: $25 \times$ doc10: 4; doc13: $25 \times$ doc17: 7. Cf. below:

\begin{tabular}{|c|c|c|}
\hline DOC & TOKENS & KWs \\
\hline 1 & 2561 & $\mathbf{2 5}$ \\
\hline 2 & 3667 & 14 \\
\hline 3 & 3333 & 11 \\
\hline 4 & 2358 & $\mathbf{2 5}$ \\
\hline 5 & 3183 & 13 \\
\hline 6 & 2835 & 15 \\
\hline
\end{tabular}

${ }^{7}$ We should point out that we compared spoken texts (SourceC) with written ones (RefC). Therefore, we would like to examine the possible influence of the reference corpus (different register) by means of further analyses in the future.

${ }^{8}$ For example when set to more than $25 \mathrm{KWs}$, the application signalizes failure of the database and it stops the whole process. 


\begin{tabular}{|c|c|c|}
\hline DOC & TOKENS & KWs \\
\hline 7 & 3949 & 20 \\
\hline 8 & 2449 & 20 \\
\hline 9 & 4537 & 13 \\
\hline 10 & 2316 & 4 \\
\hline 11 & 3547 & 20 \\
\hline 12 & 2306 & 14 \\
\hline 13 & 3042 & $\mathbf{2 5}$ \\
\hline 14 & 3706 & $\mathbf{2 5}$ \\
\hline 15 & 2860 & 11 \\
\hline 16 & 3916 & $\mathbf{2 5}$ \\
\hline 17 & 2935 & 7 \\
\hline 18 & 3874 & 21 \\
\hline 19 & 2530 & 21 \\
\hline 20 & 2790 & 14 \\
\hline MEAN & $\mathbf{3 1 3 4 . 7 0}$ & $\mathbf{1 7 . 1 5}$ \\
\hline
\end{tabular}

Tab. 7. The resulting number of KWs in KER

The TF*IDF method generates approximately the same amount of words as analysis of keywords, 340 vs. 300, but the resulting structures of POS differ significantly (compare Tables 6 and 8). TF*IDF actually detects only nouns (85\%) and adjectives (14\%), with the exceptions of $h m$ (a particle) and ježiš (an interjection ).

\begin{tabular}{|l|r|r|}
\hline \multicolumn{1}{|c|}{ POS } & FREQ & FREQ (\%) \\
\hline Noun & $\mathbf{2 9 1}$ & $\mathbf{8 4 . 8 4}$ \\
\hline Adj & $\mathbf{4 9}$ & $\mathbf{1 4 . 2 9}$ \\
\hline Interj & 2 & 0.58 \\
\hline Part & 1 & 0.29 \\
\hline Total & $\mathbf{3 4 3}$ & $\mathbf{1 0 0 . 0 0}$ \\
\hline
\end{tabular}

Tab. 8. Frequency distribution of POS in KER

The results document an important characteristic of TF*IDF: the method truly effectively eliminates all phatic expressions, hesitations, responses, and other phenomena that occur in spoken texts very frequently. In the final list, even certain autosemantic POS are missing, particularly verbs and adverbs. Generally we can conclude that the TF*IDF method appears as the most promising; the extracted words can certainly be considered as thematically relevant, their number is not too high and it needs no reduction (necessary if analysis of keywords is applied). During testing we observed that the results were influenced by the length of the analysed text (the setting of elementary parameters was constant, TF*IDF threshold level + max. number of $\mathrm{KWs}$ ): the longer the text was the less words appeared in the list of Kws. 


\section{CONCLUSION}

The TF*IDF seems to be a good alternative that can solve or eliminate the drawbacks of respective variant methods. Analysis of KWs generates an extensive list of prominent units that needs reduction while the TC method often results in very short or even empty lists of thematic words. We are aware of the fact that more analyses will have to be carried out, testing more extensive materials and various types of texts (prepared vs. unprepared spoken texts) in order to map out the character of the TF*IDF method and to find optimal settings of the key parameters.

\section{References}

[1] Cvrček, V., and Vondřička, P. (2013). KWords. Praha. Accessible at: http: / / kwords . korpus. Cz .

[2] Matlach, V., Kubát, M., and Čech, R. (2014). QUITA - Quantitative Text Analyzer. Olomouc. Accessible at: https://code.google.com/archive/p/oltk/.

[3] Libovický, J. (2016). KER - Keyword Extractor. Praha. Accessible at: https : / / I indat. mff.cuni.cz/services/ker/.

[4] Pořízka, P. (2009). Olomouc Corpus of Spoken Czech: characterization and main features of the project. Linguistik online, 38(2), pages 35-43.

[5] Straka, M., and Straková, J. (2014). MorphoDiTa: Morphological Dictionary and Tagger. Praha. Accessible at: http://lindat.mff.cuni.cz/services/morphodita/.

[6] Šmerk, P. (2009). Majka-Morphological Analysis of Czech. Brno. Accessible at: https : / / nlp.fi.muni.cz/czech-morphology-analyser/ .

[7] Stubbs, M. (1996). Text and Corpus Analysis. Oxford.

[8] Scott, M., and Tribble, Ch. (2006). Textual Patterns. Key words and Corpus Analysis in Language Education. Amsterdam - Philadelphia.

[9] Anthony, L. (2019). AntConc. Tokyo. Accessible at: http: //www . laurenceanthony . net/software.

[10] Čech, R. (2016). Tematická koncentrace textu v češtině. Praha.

[11] Rajaraman, A., Ullman, J.D. (2011). Data Mining. In Leskovec, J. et al., Mining of Massive Datasets. pages 1-17. 